\title{
The Stimulatory Action and the Development of Tolerance to Caffeine Is Associated with Alterations in Gene Expression in Specific Brain Regions
}

\author{
Per Svenningsson, George G. Nomikos, and Bertil B. Fredholm \\ Section of Molecular Neuropharmacology, Department of Physiology and Pharmacology, Karolinska Institutet, \\ 17177 Stockholm, Sweden
}

\begin{abstract}
We sought neurochemical correlates to the stimulatory action of caffeine in rats and to adaptations during development of tolerance. Acute intraperitoneal injections of caffeine $(7.5 \mathrm{mg} /$ $\mathrm{kg}$ ) increased locomotion and NGFI-A mRNA, a marker of neuronal activity, in the hippocampal area CA1, but decreased NGFI-A mRNA in rostral striatum and nucleus accumbens. Rats that received caffeine $(0.3 \mathrm{gm} / \mathrm{l})$ in their drinking water for $14 \mathrm{~d}$ developed tolerance to the stimulatory effect of a challenge with caffeine $(7.5 \mathrm{mg} / \mathrm{kg})$ and responded with a less pronounced decrease of NGFI-A mRNA in rostral striatum and nucleus accumbens. Metabolism of caffeine to its active metabolites was increased in tolerant animals, but the total level of active metabolites in brain was not significantly altered. Thus, there are changes in caffeine metabolism after long-term caffeine treatment, but they cannot explain development of tolerance.
\end{abstract}

Caffeine is the most regularly consumed psychostimulant in the world. The average daily intake is $200-500 \mathrm{mg} / \mathrm{d}$ per person in the United States and the European countries. In laboratory animals, low doses of caffeine induce place preference (Brockwell et al., 1991) and increase motor activity (Boissier and Simon, 1965; Thithapandha et al., 1972; Snyder et al., 1981). Tolerance develops rapidly to the stimulatory effects of caffeine and its metabolite theophylline on locomotion (Holtzman and Finn, 1988; Holtzman et al., 1991; Kaplan et al., 1993; Lau and Falk, 1995). This tolerance develops regardless of whether caffeine is administered orally (Holtzman et al., 1991), intraperitoneally (Lau and Falk, 1995), or subcutaneously via mini-pumps (Kaplan et al., 1993), but no cross-tolerance with amphetamine and cocaine is seen (Holtzman and Finn, 1988).

There is some evidence that the tolerance to caffeine depends on an altered metabolism (Daly, 1993; Lau and Falk, 1995). Other studies have emphasized the importance of adaptive changes in the number of adenosine receptors for the develop-

Received Oct. 29, 1998; revised Feb. 26, 1999; accepted March 8, 1999.

This work was supported by grants from the Swedish Society for Medical Research, Swedish Medical Research Council (project no. 2553), the Knut and Alice Wallenberg Foundation, Lars Hiertas Foundation, Ake Wibergs Foundation, the Institute for Scientific Information on Coffee, Karolinska Institutet, and Biomed II. We thank Mrs. Janet Holmén for critical reading of this manuscript, and Mrs. Agneta Wallman-Johansson and Karin Lindström for expert technical help with measuring methylxanthines by high-pressure liquid chromatography and with autoradiographic studies on the affinity of methylxanthines.

Correspondence should be addressed to Dr. Per Svenningsson at the above address.

Dr. Nomikos's present address: Neuroscience Research, Lilly Corporate Center, DC 0510, Eli Lilly and Company, Indianapolis, IN 46285.

Copyright (C) 1999 Society for Neuroscience $\quad 0270-6474 / 99 / 194011-12 \$ 05.00 / 0$
Caffeine-tolerant animals had downregulated levels of adenosine $A_{2 A}$ receptors and the corresponding $m R N A$ in rostral parts of striatum, but an increased expression of adenosine $A_{1}$ receptor mRNA in the lateral amygdala. No changes in mesencephalic tyrosine hydroxylase mRNA were found in caffeinetolerant rats.

Thus, we have identified neuronal pathways that are regulated by adenosine $A_{1}$ and/or $A_{2 A}$ receptors and are targets for the stimulatory action of caffeine. Furthermore, adaptive changes in gene expression in these brain areas were associated with the development of locomotor tolerance to caffeine.

Key words: caffeine; methylxanthines; adenosine receptors; immediate early genes; striatum; drug tolerance; locomotion; in situ hybridization ment of caffeine tolerance (Daly, 1993; Fredholm, 1995). Indeed, it is believed that adenosine receptor antagonism underlies the stimulatory effects of caffeine (Fredholm, 1980; Snyder et al., 1981), and several reports show that long-term administration of caffeine can cause a small increase in the number of $A_{1}$ receptors in several different brain regions (Fredholm, 1982; Ramkumar et al., 1988; Johansson et al., 1993). However, the functional role of such an upregulation is open to question (Holtzman et al., 1991; Georgiev et al., 1993; Kaplan et al., 1993), and mechanisms other than changes in $A_{1}$ receptor number probably underlie the development of caffeine tolerance. One possible target is $A_{2 A}$ receptors, which are expressed at high density in striatum and tuberculum olfactorium (Parkinson and Fredholm, 1990). Indeed, these receptors are known to be important for the stimulatory effect after acute administration of caffeine (Jacobson et al., 1993; Svenningsson et al., 1995a; 1997c; Ledent et al., 1997). We have also shown that a single dose of caffeine as well as of a selective $\mathrm{A}_{2 \mathrm{~A}}$ receptor antagonist at behaviorally stimulating concentrations significantly decreases the expression of mRNA for the immediate early gene NGFI-A in striatum (Svenningsson et al., 1995a, 1997c). This gene is known to be regulated via cAMP response element-binding (CREB) protein (Tsai-Morris et al., 1988), a transcription factor that is involved in cocaine reward (Carlezon et al., 1998). NGFI-A is also commonly used as a marker for increased metabolic activity in neuronal pathways (Dragunow and Faull, 1989).

In the present study, we therefore investigated the development of tolerance to low doses of caffeine that produce plasma levels similar to those commonly reached in man and related that to changes in the metabolism of caffeine. To find a neurochemical 
correlate we examined changes not only in adenosine receptors but also in the expression of NGFI-A mRNA.

\section{MATERIALS AND METHODS}

Animal treatments and measurements of locomotion. These experiments were approved by the regional animal ethical board. Male Sprague Dawley rats weighing 203-233 gm (ALAB, Stockholm, Sweden) were used. They were accustomed to the experimental procedure by being handled, injected with saline, and placed in the locomotion arena for 30 min on 2 consecutive days before the experiment. The locomotion arena $(68 \times 68 \times 45 \mathrm{~cm})$ is equipped with photocells at two levels for recording of horizontal (locomotion) and vertical (rearing) activity (Ericson et al., 1991). The following parameters were determined: horizontal activity (all counts recorded at the lower level of photocells), vertical activity (all counts recorded in the upper level of photocells), peripheral activity (counts recorded near the edges of the boxes, within $2.5 \mathrm{~cm}$ distance from the walls), forward locomotion (counts recorded at the lower level of photocells when the animal is moving in the same direction, i.e., successive interruptions of photobeams), and corner time (time spent in the corners of the boxes). Moreover, to determine locomotion in the center of the boxes, the peripheral activity was subtracted from the horizontal activity. Animals were randomly assigned to different treatment groups: animals drinking water and injected with saline $(n=14$, referred to as water+saline) or caffeine ( $n=8$, referred to as water+caffeine), and animals drinking caffeine solution and injected with saline $(n=8$, referred to as caffeine+saline) or caffeine ( $n=8$, referred to as caffeine + caffeine). In addition, for some caffeine-drinking animals receiving saline injections, caffeine was replaced with water as drinking fluid $14 \mathrm{hr}$ before the final saline injection $[n=6$, referred to as caffeine(withdrawal) + saline]. On the first experimental day, animals were injected intraperitoneally with saline or $7.5 \mathrm{mg} / \mathrm{kg}$ caffeine (Sigma, Labkemi, Stockholm, Sweden), and 15 min thereafter their locomotion was measured for $1 \mathrm{hr}$ in the locomotion arena. After the behavioral session animals were given water containing $0.3 \mathrm{gm} / 1$ caffeine or water as their only source of fluid. Daily measurements of their oral intake were made, and a difference of $1.0 \mathrm{gm}$ in bottle weight was assumed to represent $1.0 \mathrm{ml}$ of fluid consumed. After 1 and 2 weeks, animals were again injected with saline or caffeine $(7.5 \mathrm{mg} / \mathrm{kg})$, and their motor activity was measured for $1 \mathrm{hr}$. All animals were decapitated $2.75 \mathrm{hr}$ after the final behavioral session (i.e., $4 \mathrm{hr}$ after the final injections).

In a follow-up experiment, animals received intraperitoneal injections of saline $(n=8)$ or caffeine at different doses $(7.5,15,30,50$, or 100 $\mathrm{mg} / \mathrm{kg} ; n=5-8)$ and were killed $4 \mathrm{hr}$ thereafter. In addition, some animals were injected with saline $(n=5)$ or $50 \mathrm{mg} / \mathrm{kg}(n=5)$ or 100 $\mathrm{mg} / \mathrm{kg}(n=5)$ caffeine twice daily for 2 weeks and killed $4 \mathrm{hr}$ after the final injections.

Plasma levels of methylxanthines. After decapitation, trunk blood was collected from the severed neck, rapidly centrifuged, and stored at $-20^{\circ} \mathrm{C}$ until assayed for levels of methylxanthines. The procedure for the extraction and HPLC assaying of methylxanthines (caffeine, theobromine, and theophylline and/or paraxanthine) is described in detail elsewhere (Fredholm et al., 1983). The standards were obtained from Sigma (Labkemi, Stockholm, Sweden), and the very low levels of methylxanthines occasionally measured in water+saline-treated animals were considered as blank control and subtracted from values obtained in caffeinetreated animals. In an additional experiment, animals were given water containing $0.3 \mathrm{gm} / 1$ caffeine or water as their daily source of fluid as described above for 2 weeks and thereafter challenged with an intraperitoneal injection of caffeine, theophylline, paraxanthine, or theobromine at $15 \mathrm{mg} / \mathrm{kg}$ each. These animals were killed $4 \mathrm{hr}$ after the injections, and their trunk blood, kidneys, and brains (with striata dissected out separately) were collected, and levels of methylxanthines were determined.

In situ hybridization. The brains from killed animals were rapidly dissected out and frozen at $-80^{\circ} \mathrm{C}$. Thereafter coronal cryostat sections $(14 \mu \mathrm{m}$ thick) were cut at $+3.20,+1.20,+0.48,-0.92,-3.14$, and -5.20 $\mathrm{mm}$ from bregma and thaw-mounted on poly-L-lysine $(50 \mu \mathrm{g} / \mathrm{ml})$-coated slides. The following probes were used for in situ hybridization: NGFI-A, complementary to rat NGFI-A mRNA encoding amino acids 2-16 of the NGFI-A protein (Milbrandt, 1987); tyrosine hydroxylase, complementary to nucleotides $1441-1488$ of the rat tyrosine hydroxylase protein (Lamouroux et al., 1982); $\mathrm{A}_{1}$ receptor, complementary to nucleotides 985-1032 of the rat $A_{1}$ receptor (Mahan et al., 1991); and $A_{2 \mathrm{~A}}$ receptor, complementary to nucleotides $916-959$ of the $\operatorname{dog} A_{2 \mathrm{~A}}$ receptor (Schiffmann et al., 1990). All probes were radiolabeled using terminal deoxyribonucleotidyl transferase (Pharmacia LKB, Uppsala, Sweden) and $\alpha-{ }^{35} \mathrm{~S}-$
dATP (DuPont-NEN, Stockholm, Sweden) to a specific activity of $\sim 10^{9}$ $\mathrm{cpm} / \mu \mathrm{g}$. Mounted sections were hybridized in a mixture containing $50 \%$ formamide (Fluka, Buchs, Switzerland), $4 \times$ sodium saline chloride, $1 \times$ Denhardt's solution, $1 \%$ sarcosyl, $0.02 \mathrm{M} \mathrm{NaPO}_{4}, \mathrm{pH} 7.0,10 \%$ dextran sulfate, $0.5 \mathrm{mg} / \mathrm{ml}$ yeast tRNA (Sigma, Labkemi, Stockholm, Sweden), $0.06 \mathrm{M}$ dithiothreitol, $0.1 \mathrm{mg} / \mathrm{ml}$ sheared salmon sperm DNA, and $10^{7}$ $\mathrm{cpm} / \mathrm{ml}$ of probe. After hybridization for $16 \mathrm{hr}$ at $42^{\circ} \mathrm{C}$, the sections were washed four times for $15 \mathrm{~min}$ in $1 \times$ sodium saline chloride at $55^{\circ} \mathrm{C}$. Thereafter they were dipped briefly in water and in 70, 95, and $99.5 \%$ ethanol, and dried. The dry sections were apposed to Hyperfilm $\beta$-max film (Amersham, Solna, Sweden) for 1-2 weeks. Some sections were thereafter dipped in NTB-3 emulsion (Kodak, Järfälla, Sweden) and exposed for 2 months.

The autoradiographic films from the in situ hybridization experiments were analyzed by using the Microcomputer Imaging Device system (M4, Imaging Research, Ontario, Canada). The system was calibrated with a Kodak density wedge, and the results are presented as optical density values.

Ligand binding autoradiography. Saturation experiments with $\left[{ }^{3} \mathrm{H}\right] 1,3-$ dipropyl-8-cyclopentylxanthine (DPCPX; 0.05, 0.25, 0.5, 1, 2.5, 7.5, 15, and $30 \mathrm{~nm})(120 \mathrm{Ci} / \mathrm{mmol}$; DuPont, New England Nuclear, Stockholm, Sweden), a selective $A_{1}$ receptor antagonist, and $\left[{ }^{3} \mathrm{H}\right] 5$-amino-7-(2phenylethyl)-2-(2-furyl)-pyrazolo(4,3-e)-1,2,4-triazolo[1,5-c]pyrimidine (SCH 58261; 0.1, 0.25, 0.5, 1, 2.5, 5, and $10 \mathrm{nM})(68.6 \mathrm{Ci} / \mathrm{mmol}$; a gift from Dr. Ennio Ongini, Schering-Plow, Milan, Italy), a selective $A_{2 \mathrm{~A}}$ receptor antagonist, were performed as described elsewhere (Svenningsson et al., $1997 \mathrm{c})$. The nonselective adenosine receptor agonist $5^{\prime}-N$ ethylcarboxamidoadenosine (NECA; $100 \mu \mathrm{M}$ ) was used to define nonspecific binding at each concentration. To determine the potency of methylxanthines (caffeine, theophylline, paraxanthine, and theobromine), they were added at concentrations of 1, 3, 10, 30, 100, 300, and $1000 \mu \mathrm{M}$ with $1 \mathrm{nM}\left[{ }^{3} \mathrm{H}\right] \mathrm{N}^{6}$-cyclohexyladenosine $(\mathrm{CHA} ; 34.4 \mathrm{Ci} / \mathrm{mmol}$; DuPont-NEN), a selective $A_{1}$ receptor agonist, or $2 \mathrm{~nm}\left[{ }^{3} \mathrm{H}\right] 2-[p-(2-$ carbonylethyl] phenethylamino]-5'-N-ethylcarboxamidoadenosine (CGS 21680; $48.1 \mathrm{Ci} / \mathrm{mmol}$; DuPont-NEN), a selective $\mathrm{A}_{2 \mathrm{~A}}$ receptor agonist, as described in detail elsewhere (Parkinson and Fredholm, 1990; Johansson et al., 1993). It has previously been shown that caffeine, which is very water soluble and a low-affinity ligand at adenosine receptors, does not remain in the sections after the initial wash steps and therefore that caffeine remaining in the sections does not affect the results (Johansson et al., 1997). The dried sections together with plastic tritium standards (Amersham, Solna, Sweden) were apposed to ${ }^{3}$ Hyperfilm (Amersham) for 5 weeks. The autoradiograms were analyzed with a Microcomputer Imaging Device system (M4). Optical density values were converted to binding density (femtomol per milligram of gray matter) using the plastic tritium standards and specific activity of the radioligands. The $\mathrm{IC}_{50}$ values for $\left[{ }^{3} \mathrm{H}\right] \mathrm{CHA}$ and $\left[{ }^{3} \mathrm{H}\right] \mathrm{CGS} 21680$ were converted to $K_{\mathrm{i}}$ values according to the Cheng-Prusoff equation using the $K_{\mathrm{D}}$ values for the ligands given in the cited publications $\left(0.32 \mathrm{~nm}\right.$ for $\left[{ }^{3} \mathrm{H}\right] \mathrm{CHA} ; 2 \mathrm{~nm}$ for $\left[{ }^{3} \mathrm{H}\right] \mathrm{CGS}$ 21680).

Statistics. Data obtained from the behavioral experiments were expressed as total activity counts over 60 min sessions (see Figs. 1, 2) and statistically evaluated by using either a three-way (oral water or caffeine/ saline or caffeine challenge/days) ANOVA with repeated measures (days) (see Fig. 1) or a two-way (oral water or caffeine/saline or caffeine challenge) ANOVA (see Fig. 2). In all cases, post hoc comparisons were made by using the Tukey highest significant difference test for unequal group sample sizes (CSS:Statistical software).

Optical density values from the different treatment groups from the in situ hybridization experiments were statistically evaluated by using oneway ANOVAs for each region. To determine whether there were significant differences between individual treatment groups, pairwise comparisons were made using Bonferroni's test for post hoc comparisons (GraphPAD PRISM 2.1, San Diego, CA). Data from the autoradiographic experiments were fitted to a binding isotherm by nonlinear regression (GraphPAD PRISM 2.1).

For all statistical evaluations, $p<0.05$ was considered significant.

\section{RESULTS}

Daily oral intake of caffeine was estimated to be $60.2 \pm 1.6$, $57.7 \pm 1.9$, and $59.4 \pm 0.9 \mathrm{mg} \cdot \mathrm{kg}^{-1} \cdot \mathrm{d}^{-1}$ for caffeine + saline-, caffeine(withdrawal) + saline-, and caffeine + caffeine-treated animals, respectively. This is lower than those reported for rats receiving $1.0 \mathrm{gm} / 1$ caffeine in the drinking water (Johansson et 


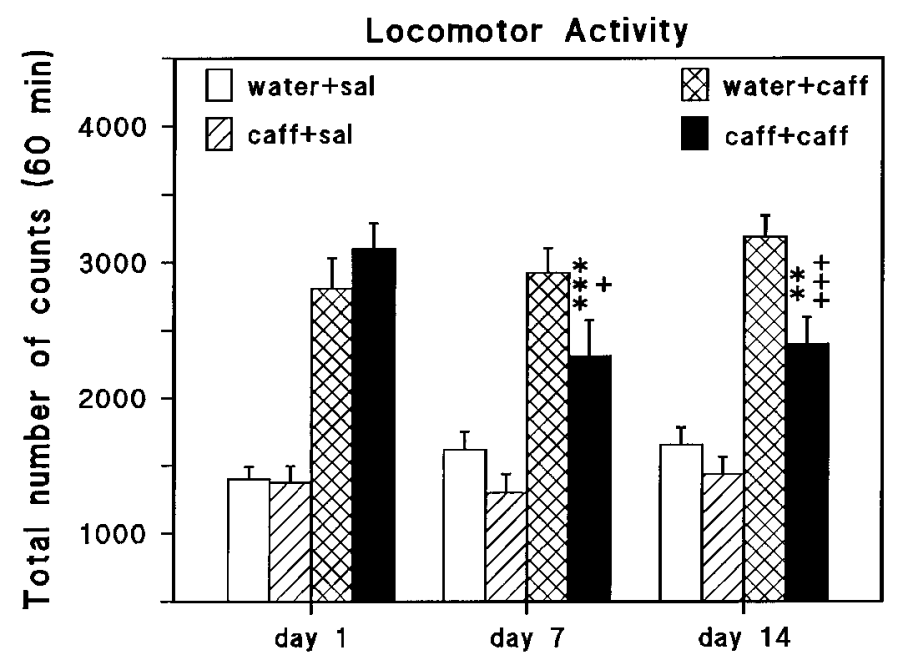

Figure 1. The development of tolerance to caffeine's ability to increase locomotor activity over a course of chronic caffeine administration. Data are expressed as mean $( \pm$ SEM) of total activity counts during a $60 \mathrm{~min}$ session. Asterisks indicate a significant difference between caffeine + saline- and caffeine + caffeine-treated animals. Plus signs indicate a significant difference between water+caffeine- and caffeine + caffeine-treated animals. ${ }^{+} p<0.05 ;{ }^{* *} p<0.01{ }^{+++,}{ }^{* * *} p<$ 0.001 .

al., 1993), but similar to those reported for mice that received 0.3 $\mathrm{gm} / \mathrm{l}$ caffeine in the drinking water (Johansson et al., 1997). The average daily volume of caffeine solution consumed was similar to the average daily volume of drug-free tap water that was consumed by the control group $(56.3 \pm 1.6,52.9 \pm 2.0$, and $55.5 \pm 0.6$ $\mathrm{ml} / \mathrm{d}$ for caffeine + saline-, caffeine(withdrawal) + saline-, and caffeine + caffeine-treated animals versus $56.9 \pm 1.6$ and $53.9 \pm$ $1.8 \mathrm{ml} / \mathrm{d}$ for water + saline-and water + caffeine-treated animals). This is in contrast to the situation in rats and mice receiving 1 gm/l caffeine (Johansson et al., 1993) who consumed smaller amounts of fluid and showed a smaller weight gain than control animals. Because this relative weight loss appears to be attributable to diuresis, the results could indicate that the renal effects of $0.3 \mathrm{gm} / 1$ caffeine in the drinking water are limited. However, the average increase in body weight of rats receiving $0.3 \mathrm{gm} / 1$ of caffeine for $14 \mathrm{~d}$ did not differ from the average weight gain of rats in the control group $(7.63 \pm 0.24,7.52 \pm 0.20$, and $7.60 \pm 0.27$ $\mathrm{gm} / \mathrm{d}$ for caffeine + saline-, caffeine (withdrawal) + saline-, and caffeine + caffeine-treated animals versus $7.26 \pm 0.18$ and $7.18 \pm$ $0.19 \mathrm{gm} / \mathrm{d}$ for water + saline- and water + caffeine-treated animals).

\section{Oral administration of caffeine leads to development of tolerance to the stimulatory effect of a challenge with caffeine}

Before the oral treatments with water or caffeine $(0.3 \mathrm{gm} / 1)$, all animals that received an intraperitoneal injection of caffeine (7.5 $\mathrm{mg} / \mathrm{kg}$ ) responded with a marked increase in locomotion as compared with their saline-treated controls (Fig. 1). After 1 week of caffeine ingestion, tolerance, although incomplete, developed to the effect of caffeine (Fig. 1). After 2 weeks the tolerance was of a similar magnitude as after 1 week. No significant changes in locomotion were found in animals that received caffeine + saline as compared with animals treated with either water+saline (Fig. 1) or caffeine(withdrawal)+saline (results not shown).
There are both quantitative and qualitative differences in locomotion in caffeine-tolerant rats

The pattern of locomotion in animals receiving caffeine in their drinking solution (caffeine + saline) did not differ from the normal pattern observed in water+saline-treated animals. However, animals receiving water+caffeine differed significantly from water + saline-treated animals in all the examined measurements of motor activity (Fig. $2 A-F$ ). That is, the animals exhibited more forward locomotion and vertical and horizontal activity, both in the periphery and in the center of the locomotion arena, and spent less time in the corners of the arena. After $14 \mathrm{~d}$ of caffeine treatment the locomotion and rearing caused by a challenge with caffeine was significantly altered (Fig. $2 A, C$ ). The locomotion in the center of the arena was markedly reduced, whereas locomotion in the periphery was unaltered (Fig. 2D,F). Accordingly, caffeine + caffeine-treated animals spent more time in the corners of the arena than the water+caffeine-treated animals (Fig. 2E). Thus, tolerance to the stimulatory effect of caffeine occurred in animals chronically exposed to caffeine in their drinking fluid. However, this tolerance was incomplete because caffeine + caffeine animals showed significantly higher scores for forward locomotion and vertical and horizontal activities (but only in the periphery) than animals treated with caffeine + saline (Fig. 2A-D). No significant differences in the pattern of motor activity were found between caffeine + saline- and caffeine(withdrawal) + saline-treated animals (data not shown).

The development of tolerance to the stimulatory effect of caffeine could be attributed to pharmacokinetic adaptations and changes in the signaling via adenosine receptors and other neurotransmitter systems such as the dopaminergic system. We have tried to elucidate the role of these different possibilities.

\section{There is an enhanced metabolism of caffeine and accumulation of active metabolites in tolerant rats}

To verify the accuracy of the caffeine injections and to estimate the levels of caffeine in chronically exposed animals, trunk blood was collected after the decapitation on day 14, and the plasma levels of caffeine were determined. Because caffeine forms several active metabolites-theophylline, theobromine, and paraxanthine-we also measured the levels of these methylxanthines. As shown in Table 1, there was almost no caffeine, but there were substantial amounts of its metabolites in caffeine + saline-treated animals. Similarly, in caffeine + caffeine-treated animals the levels of caffeine were considerably lower than those of theophylline/ paraxanthine and theobromine. By contrast, in water+caffeinetreated animals the level of caffeine was markedly higher than its metabolites. The plasma levels of methylxanthines were very close to the limit of detection (i.e., corresponding to those in water + saline animals) in caffeine(withdrawal)+saline animals.

These results could indicate that part of the tolerance to caffeine is caused by increased metabolism. However, the decrease in caffeine levels was accompanied by an increase in theophylline, paraxanthine, and theobromine. All of these methylxanthines act as antagonists at adenosine receptors, albeit with somewhat different affinities, so there is reason to assume that the pharmacological effects may correlate better with the summed concentrations of caffeine and its active metabolites than with the concentration of caffeine alone. We therefore determined the potency of the four methylxanthines at striatal $A_{1}$ and $A_{2 A}$ receptors by using autoradiography (Fig. 3). On the basis of this 

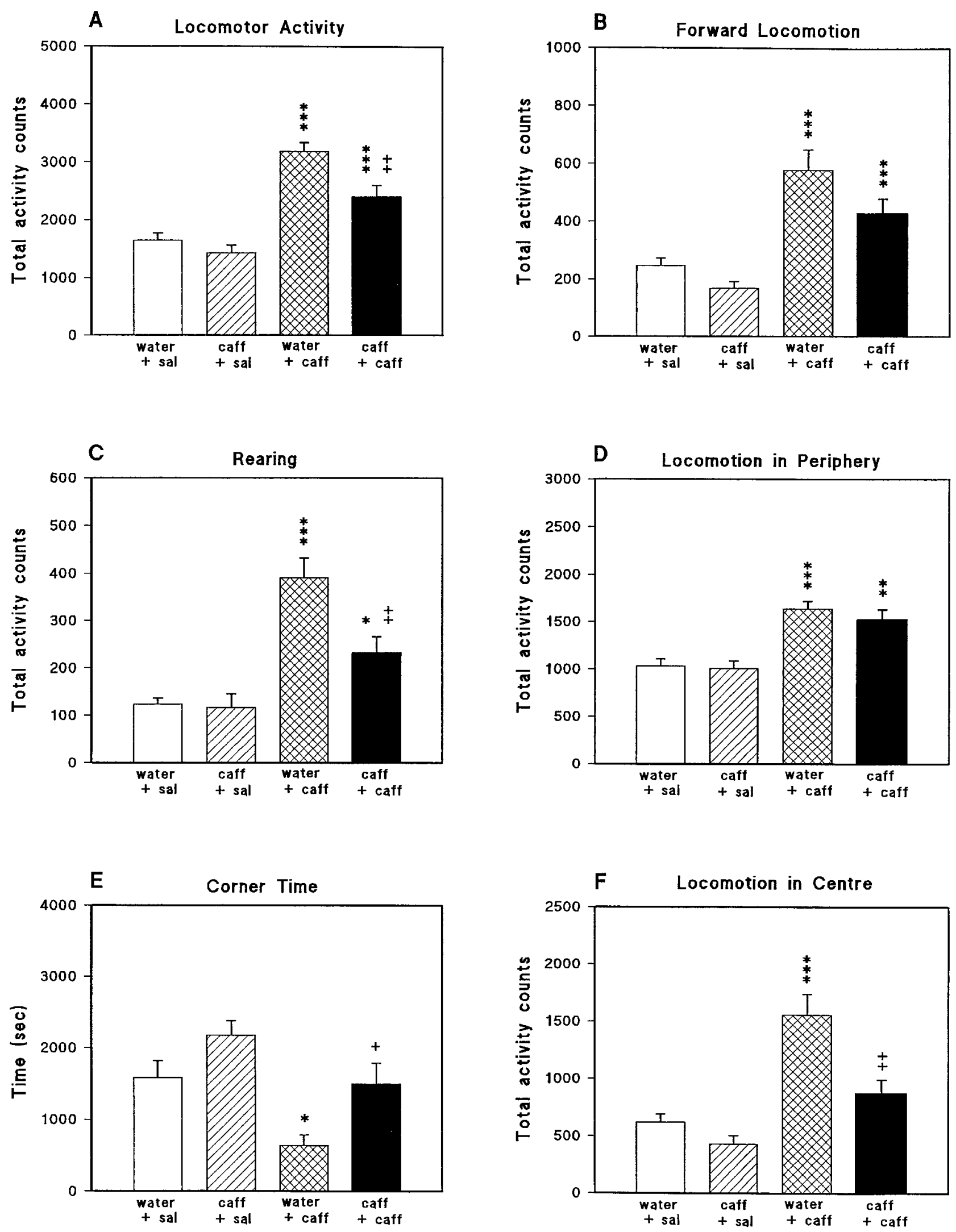

Figure 2. Effects of saline or caffeine $(7.5 \mathrm{mg} / \mathrm{kg})$ challenge on locomotor activity $(A)$, forward locomotion $(B)$, rearing $(C)$, locomotion in periphery $(D)$, corner time $(E)$, and locomotion in center $(F)$ in animals treated chronically with water or caffeine $(0.3 \mathrm{gm} / 1)$ for $14 \mathrm{~d}$. Data are expressed as mean $( \pm$ SEM) of total activity counts during a $60 \mathrm{~min}$ session. Asterisks indicate a significant difference between caffeine + saline- and caffeine + caffeine-treated animals. Plus signs indicate a significant difference between water + caffeine- and caffeine + caffeine-treated animals. ${ }^{+} p<0.05 ;{ }^{* *} p<0.01 ;{ }^{+++}, *^{* *} p<$ 0.001 . 


\begin{tabular}{|c|c|c|c|c|c|}
\hline Challenge & Chronic treatment & Theobromine & Theophylline/paraxanthine & Caffeine & Total methylxanthines (weighted) \\
\hline \multirow[t]{2}{*}{ Saline } & Caffeine & $2.13 \pm 0.22$ & $4.35 \pm 0.63$ & $0.40 \pm 0.08$ & $11.8 \pm 1.73$ \\
\hline & Caffeine (withdrawal) & $0.52 \pm 0.49$ & $0.72 \pm 0.41$ & $0.0 \pm 0.0$ & $1.64 \pm 0.97$ \\
\hline \multirow[t]{2}{*}{ Caffeine } & Water & $2.57 \pm 0.21$ & $10.9 \pm 0.86$ & $14.8 \pm 1.69$ & $42.5 \pm 3.73$ \\
\hline & Caffeine & $6.86 \pm 0.89$ & $17.8 \pm 2.58$ & $3.73 \pm 1.11$ & $49.6 \pm 7.63$ \\
\hline
\end{tabular}

Weighted values (based on $K_{\mathrm{i}}$ values for displacement of $\left[{ }^{3} \mathrm{H}\right] \mathrm{DPCPX}$ and $\left[{ }^{3} \mathrm{H}\right] \mathrm{SCH} 58261$ binding: caffeine, 1 : theophylline/paraxanthine, 2.55; theobromine, 0.14).

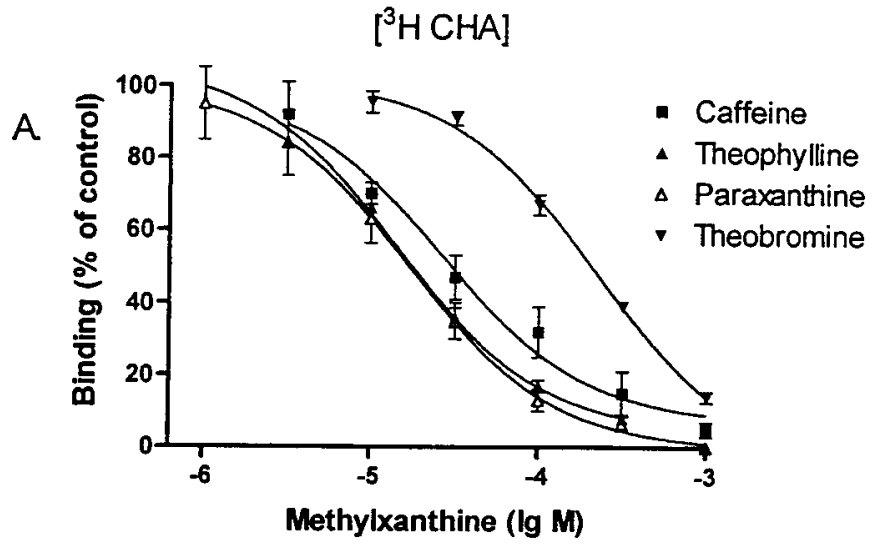

$\left[{ }^{3} \mathrm{H}\right] \mathrm{CGS} 21680$

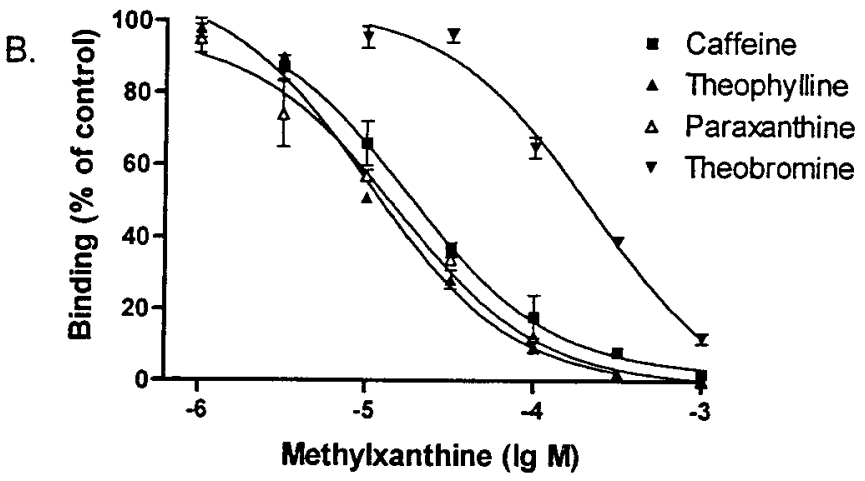

Figure 3. Potency of caffeine, theophylline, paraxanthine, and theobromine as antagonists at striatal $\mathrm{A}_{1}$ and $\mathrm{A}_{2 \mathrm{~A}}$ receptors. $A$ shows displacement of binding of $1 \mathrm{nM}\left[{ }^{3} \mathrm{H}\right] \mathrm{CHA}$ from striatal $\mathrm{A}_{1}$ receptors. Means $( \pm$ SEM) from duplicate determinations from two separate experiments. $B$ shows displacement of binding of $2 \mathrm{~nm}\left[{ }^{3} \mathrm{H}\right] \mathrm{CGS} 21680$ from striatal $\mathrm{A}_{2 \mathrm{~A}}$ receptors. Means ( \pm SEM) from duplicate determinations from two separate experiments. Using the $K_{\mathrm{D}}$ value for CHA determined earlier (Johansson et al., 1993), the following $K_{\mathrm{i}}$ values for $\mathrm{A}_{1}$ receptors were calculated: caffeine $20.2 \mu \mathrm{M}$, theophylline $4.7 \mu \mathrm{M}$, paraxanthine $5.0 \mu \mathrm{M}$, theobromine $98 \mu \mathrm{M}$. Using the $K_{\mathrm{D}}$ value for CGS 21680 determined earlier (Parkinson and Fredholm, 1990), the following $K_{\mathrm{i}}$ values for $\mathrm{A}_{2 \mathrm{~A}}$ receptors were calculated: caffeine $8.8 \mu \mathrm{M}$, theophylline $5.1 \mu \mathrm{M}$, paraxanthine $7.6 \mu \mathrm{M}$, theobromine $109 \mu \mathrm{M}$.

information, each of the methylxanthines was weighted according to its affinity for $A_{1}$ and $A_{2 A}$ receptors and thereafter added together. The weighted values were determined by using the means of $K_{\mathrm{i}}$ values for $\left[{ }^{3} \mathrm{H}\right] \mathrm{CHA}$ and $\left[{ }^{3} \mathrm{H}\right] \mathrm{CGS} 21680$ displacement; 1 for caffeine, 2.13 for paraxanthine, 2.96 for theophylline, and 0.14 for theobromine. Calculated using this procedure, the plasma levels of weighted methylxanthines tended to be higher in caffeine + caffeine- than in the water + caffeine-treated animals (Table 1).

\section{Caffeine penetrates the blood-brain barrier several times better than its metabolites}

Previous work (Lau and Falk, 1995) has indicated that the plasma levels of methylxanthines might not correspond adequately with those in the brain. To further investigate this issue and to confirm that caffeine is metabolized more rapidly in tolerant rats, animals received water containing $0.3 \mathrm{gm} / 1$ caffeine or ordinary tap water as their daily source of fluid as described above for 2 weeks and were thereafter challenged with an intraperitoneal injection of either caffeine, theophylline, paraxanthine, or theobromine at 15 $\mathrm{mg} / \mathrm{kg}$ each. The daily intake of water and caffeine solution was almost identical in the two groups $(56.7 \pm 0.57$ and $54.7 \pm 0.21$ $\mathrm{ml} / \mathrm{d}$, respectively), leading to an amount of caffeine ingestion at $58.1 \pm 0.50 \mathrm{mg} \cdot \mathrm{kg}^{-1} \cdot \mathrm{d}^{-1}$ for oral caffeine-treated animals. The weight gain was also very similar: $7.90 \pm 0.10 \mathrm{gm} / \mathrm{d}$ in watertreated and $7.83 \pm 0.12 \mathrm{gm} / \mathrm{d}$ in caffeine-treated animals.

Each of the methylxanthines was readily transferred to the plasma from the gastrointestinal tract as well as the intraperitoneal space (Table 2). In water-drinking animals, an injection of caffeine led to high levels of caffeine in the CNS with the ratio between levels in striatum and kidney being 0.62 . By contrast, the striatal levels of all the other examined methylxanthines were relatively much lower than in the kidney. The ratios striatum/ kidney were 0.24 for theophylline, 0.07 for paraxanthine, and 0.25 for theobromine. Intraperitoneal injections of theophylline, paraxanthine, or theobromine also led to much higher levels in the kidney than in the striatum, and the ratios striatum/kidney were 0.26 for theophylline, 0.11 for paraxanthine, and 0.29 for theobromine. For all examined methylxanthines, levels similar to those measured in striatum were found when the remaining part of the brain (i.e., without striatum) was examined (results not shown). As in the first experiment described above, caffeine was more rapidly metabolized in caffeine-drinking than waterdrinking animals (Table 2). However, the total amount of weighted methylxanthines was not significantly altered, even in striatum. The increased metabolism of caffeine after chronic exposure was unique for this methylxanthine, and none of the other examined methylxanthines were more rapidly metabolized in caffeine-drinking animals (Table 2).

\section{Long-term treatment with caffeine causes an increase of $A_{1}$ receptor mRNA in lateral amygdala, but a decrease in $A_{2 A}$ receptors and their corresponding mRNA in striatum}

The distribution of $\mathrm{A}_{1}$ and $\mathrm{A}_{2 \mathrm{~A}}$ receptors and their corresponding mRNAs agreed with previous studies. The brain areas in which caffeine-mediated alterations in adenosine receptors and their mRNAs were sought are indicated in Figure 4. In rats receiving oral caffeine (caffeine + saline), $\mathrm{A}_{1}$ receptor mRNA was found to be increased in the lateral amygdala and tended to be increased in 


\begin{tabular}{|c|c|c|c|c|c|c|}
\hline Challenge & Chronic treatment & Theobromine & Paraxanthine & Theophylline & Caffeine & Total methylxanthines (weighted) \\
\hline \multicolumn{7}{|l|}{ Plasma } \\
\hline \multirow[t]{2}{*}{ Caffeine } & Water & $2.43 \pm 0.25$ & $7.41 \pm 1.76$ & $7.54 \pm 0.78$ & $19.3 \pm 5.61$ & $57.7 \pm 11.7$ \\
\hline & Caffeine & $3.04 \pm 0.21$ & $11.7 \pm 3.18$ & $9.93 \pm 1.14$ & $3.98 \pm 1.05$ & $58.8 \pm 11.2$ \\
\hline \multirow[t]{2}{*}{ Theophylline } & Water & $0.25 \pm 0.13$ & $0.00 \pm 0.00$ & $55.6 \pm 3.05$ & $0.00 \pm 0.00$ & \\
\hline & Caffeine & $1.25 \pm 0.82$ & $0.24 \pm 0.24$ & $49.1 \pm 3.54$ & $0.00 \pm 0.00$ & \\
\hline \multirow[t]{2}{*}{ Paraxanthine } & Water & $0.00 \pm 0.00$ & $26.4 \pm 5.63$ & $1.44 \pm 0.16$ & $0.00 \pm 0.00$ & \\
\hline & Caffeine & $0.79 \pm 0.12$ & $24.8 \pm 2.93$ & $1.86 \pm 0.16$ & $0.00 \pm 0.00$ & \\
\hline \multirow[t]{2}{*}{ Theobromine } & Water & $14.6 \pm 2.21$ & $0.62 \pm 0.36$ & $2.29 \pm 0.16$ & $0.00 \pm 0.00$ & \\
\hline & Caffeine & $10.7 \pm 0.17$ & $1.14 \pm 0.24$ & $2.95 \pm 0.47$ & $0.00 \pm 0.00$ & \\
\hline \multicolumn{7}{|l|}{ Striatum } \\
\hline \multirow[t]{2}{*}{ Caffeine } & Water & $0.98 \pm 0.07$ & $1.60 \pm 0.57$ & $2.04 \pm 0.05$ & $12.8 \pm 3.98$ & $22.4 \pm 5.35$ \\
\hline & Caffeine & $1.22 \pm 0.14$ & $1.85 \pm 0.10$ & $2.94 \pm 0.28$ & $5.98 \pm 0.68$ & $18.8 \pm 1.74$ \\
\hline \multirow[t]{2}{*}{ Theophylline } & Water & $0.02 \pm 0.02$ & $0.00 \pm 0.00$ & $12.9 \pm 0.94$ & $0.00 \pm 0.00$ & \\
\hline & Caffeine & $0.23 \pm 0.06$ & $0.00 \pm 0.00$ & $12.4 \pm 1.09$ & $0.00 \pm 0.00$ & \\
\hline \multirow[t]{2}{*}{ Paraxanthine } & Water & $0.00 \pm 0.00$ & $4.73 \pm 0.75$ & $0.00 \pm 0.00$ & $0.00 \pm 0.00$ & \\
\hline & Caffeine & $0.23 \pm 0.09$ & $3.08 \pm 1.61$ & $0.28 \pm 0.28$ & $0.00 \pm 0.00$ & \\
\hline \multirow[t]{2}{*}{ Theobromine } & Water & $4.42 \pm 0.54$ & $0.00 \pm 0.00$ & $0.00 \pm 0.00$ & $0.00 \pm 0.00$ & \\
\hline & Caffeine & $4.24 \pm 0.36$ & $0.00 \pm 0.00$ & $0.00 \pm 0.00$ & $0.00 \pm 0.00$ & \\
\hline \multicolumn{7}{|l|}{ Kidney } \\
\hline \multirow[t]{2}{*}{ Caffeine } & Water & $3.85 \pm 0.57$ & $24.2 \pm 3.92$ & $8.59 \pm 1.00$ & $21.0 \pm 5.75$ & $98.6 \pm 17.1$ \\
\hline & Caffeine & $5.77 \pm 0.37$ & $29.9 \pm 2.98$ & $10.7 \pm 0.76$ & $6.26 \pm 1.68$ & $103 \pm 10.3$ \\
\hline \multirow[t]{2}{*}{ Theophylline } & Water & $0.00 \pm 0.00$ & $0.00 \pm 0.00$ & $49.7 \pm 3.43$ & $0.00 \pm 0.00$ & \\
\hline & Caffeine & $0.71 \pm 0.11$ & $2.30 \pm 2.30$ & $42.8 \pm 8.80$ & $0.00 \pm 0.00$ & \\
\hline \multirow[t]{2}{*}{ Paraxanthine } & Water & $0.09 \pm 0.03$ & $43.5 \pm 6.52$ & $0.81 \pm 0.33$ & $0.00 \pm 0.00$ & \\
\hline & Caffeine & $0.84 \pm 0.15$ & $37.0 \pm 2.45$ & $3.13 \pm 0.08$ & $0.00 \pm 0.00$ & \\
\hline \multirow[t]{2}{*}{ Theobromine } & Water & $15.3 \pm 1.80$ & $0.00 \pm 0.00$ & $1.53 \pm 0.43$ & $0.00 \pm 0.00$ & \\
\hline & Caffeine & $13.8 \pm 0.41$ & $2.10 \pm 0.55$ & $2.60 \pm 0.53$ & $0.00 \pm 0.00$ & \\
\hline
\end{tabular}

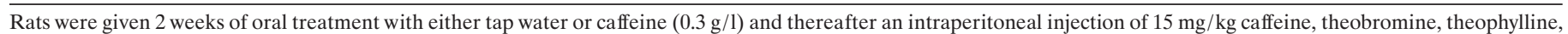

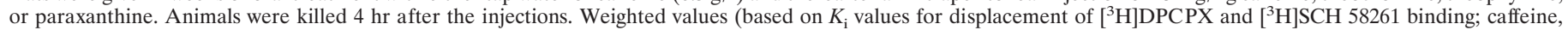
1; paraxanthine, 2.13; theophylline, 2.96; theobromine, 0.14).

hippocampal areas, but remained unchanged in other examined areas as compared with their water-treated controls (water+saline) (Table 3, Fig. 5E,F). The increase of $\mathrm{A}_{1}$ receptor mRNA in the lateral amygdala was more pronounced in animals from which caffeine had been withdrawn (Table 3). The presence of $\left[{ }^{3} \mathrm{H}\right] \mathrm{DPCPX}$-binding in the lateral amygdala was established (results not shown), but because of the rather small size of this nucleus, no attempts were made to quantitate the number of binding sites. Caffeine treatment had no significant effects on binding sites for $\mathrm{A}_{1}$ receptors, as detected by [ $\left.{ }^{3} \mathrm{H}\right] \mathrm{DPCPX}$, in any of the regions where measurements could be made (Fig. 6A).

A significant reduction of $\mathrm{A}_{2 \mathrm{~A}}$ receptor mRNA was detected in the rostral parts of striatum in caffeine-treated animals (caffeine + saline) as compared with rats receiving water (water + saline) (Table 3, Fig. 5C,D). Moreover, autoradiography revealed also a decrease of binding sites for the selective $\mathrm{A}_{2 \mathrm{~A}}$ receptor antagonist $\left[{ }^{3} \mathrm{H}\right] \mathrm{SCH} 58261$ in caffeine-treated animals (Figs. $5 A, B, 6 B$ ). In contrast to the regulation of $\mathrm{A}_{1}$ receptor mRNA in the lateral amygdala, the decreases of both $\mathrm{A}_{2 \mathrm{~A}}$ receptor mRNA and protein levels returned toward control levels in animals in which caffeine had been withdrawn 14 hr earlier (caffeine(withdrawal)+saline) (Table 3, Fig. 6B). This rapid normalization may depend on a rapid turnover of $\mathrm{A}_{2 \mathrm{~A}}$ receptor mRNA. Indeed, in PC 12 cells, a cell line expressing native $A_{2 A}$ receptors, $A_{2 A}$ mRNA has a short halflife (1.2 hr) (Saitoh et al., 1994).

\section{Single or repeated intraperitoneal injections of moderate to high concentrations of caffeine downregulate $A_{2 A}$ receptor mRNA}

The ability of caffeine to decrease the gene expression for $A_{2 A}$ receptors in the rostral striatum was somewhat surprising. To further examine effects of caffeine on $A_{2 A}$ receptor mRNA, animals were given acute intraperitoneal injections of saline or caffeine at several different doses $(7.5,15,30,50$, and $100 \mathrm{mg} / \mathrm{kg})$. A significant decrease in $\mathrm{A}_{2 \mathrm{~A}}$ receptor mRNA was found after 50 and $100 \mathrm{mg} / \mathrm{kg}$ caffeine (Fig. $7 A$ ). A significant decrease was also found in animals that received 50 or $100 \mathrm{mg} / \mathrm{kg}$ caffeine twice daily for 2 weeks (Fig. $7 B$ ). Injections of moderate to high doses of caffeine, equivalent to $50-100 \mathrm{mg} / \mathrm{kg}$, lead to induction of the transcription factor AP-1 in striatum (Svenningsson et al., 1995b). AP-1 is a dimer composed of the products of different fos and jun immediate early genes and is involved in the regulation of a large number of target genes (Sheng and Greenberg, 1990). Because there are binding sites for AP-1 in the promotor region of the $\mathrm{A}_{2 \mathrm{~A}}$ receptor gene (Chu et al., 1996), we examined whether pretreatment with c-fos antisense oligonucleotides could inhibit caffeineinduced downregulation of this gene. For this part of the study we used slides from a previous experiment in which we confirmed that c-fos antisense oligonucleotides, but not the controls, reduced c-fos mRNA and protein (Svenningsson et al., 1997a). No effect of the c-fos antisense oligonucleotide on the caffeine-mediated downregulation of $A_{2 A}$ receptor mRNA was found (Fig. $7 C$ ). 


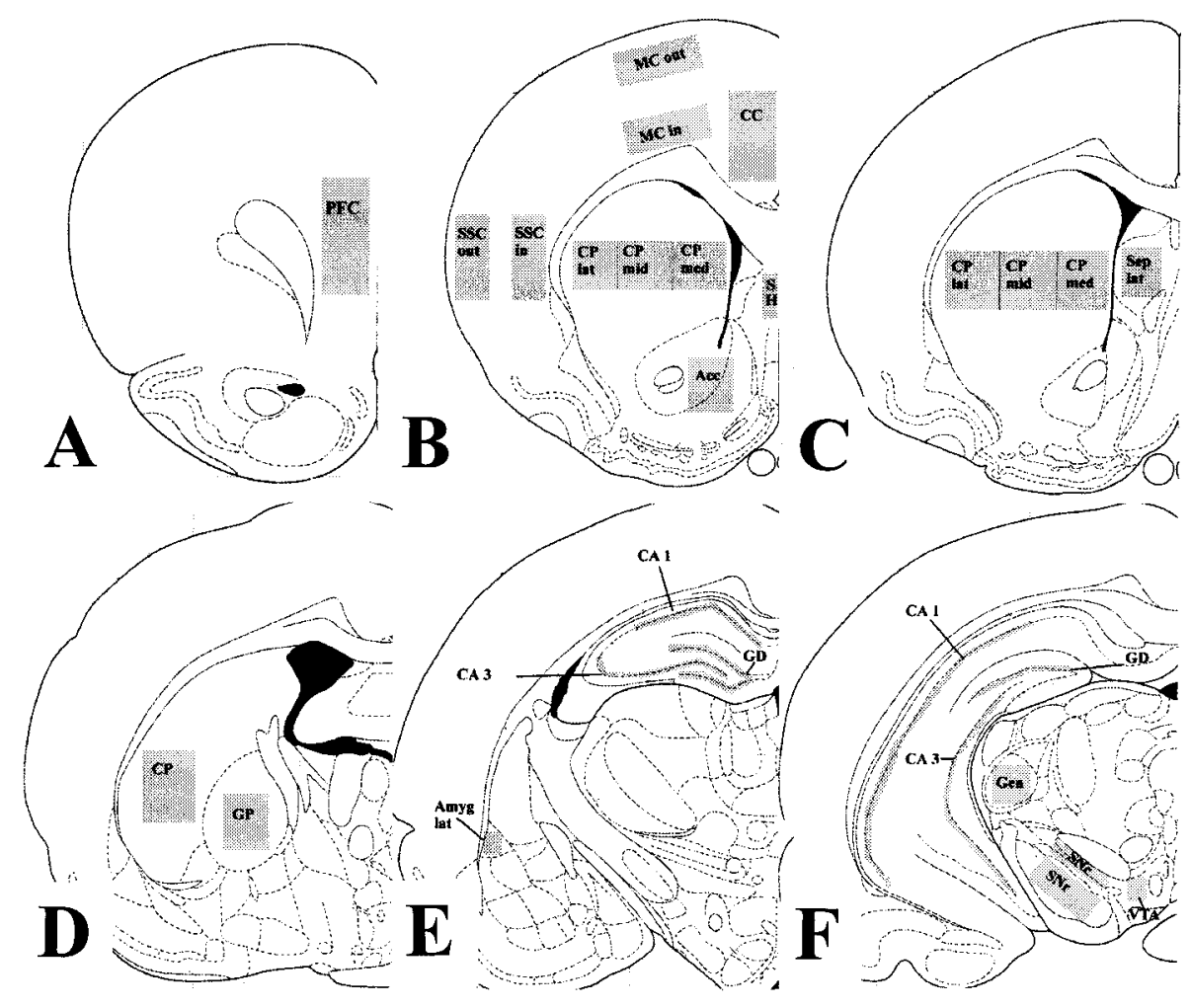

Figure 4. Quantitative measurements of gene expression and ligand binding were performed $+3.20 \mathrm{~mm}(A),+1.20 \mathrm{~mm}(B),+0.48 \mathrm{~mm}(C)$, $-0.92 \mathrm{~mm}(D),-3.14 \mathrm{~mm}(E)$, and $-5.20 \mathrm{~mm}$ $(F)$ from bregma. Gray squares delineate the regions examined. Amyg lat, Lateral amygdala; $C A$ 1, field CA 1 of Ammon's horn in hippocampus; $C A 3$, field CA 3 of Ammon's horn in hippocampus; $C C$, cingulate cortex; $C P$, caudate-putamen; $G D$, gyrus dentatus; Gen, medial geniculate nucleus; $G P$, globus pallidus; $M C$, motor cortex; $P F C$, prefrontal cortex; Sep lat, lateral septum; $S H$, septohippocampal nucleus; $S N c$, substantia nigra pars compacta; $S N r$, substantia nigra pars reticulata; $S S C$, somatosensory cortex; $V T A$, ventral tegmental area.
Table 3. Optical density values $(\times 100)$ of $A_{1}$ and $A_{2 A}$ receptor mRNA from the examined regions after indicated treatments

\begin{tabular}{llll} 
& & & $\begin{array}{l}\text { Caffeine } \\
\text { (withdrawal) } \\
\text { +saline }\end{array}$ \\
\hline Wdenosine A $A_{1}$ receptor mRNA & & \\
Nucleus accumbens & $4.16 \pm 0.29$ & $4.18 \pm 0.25$ & $3.83 \pm 0.37$ \\
CP lateral & $4.16 \pm 0.24$ & $3.98 \pm 0.18$ & $3.89 \pm 0.35$ \\
CP middle & $4.29 \pm 0.25$ & $4.13 \pm 0.14$ & $4.09 \pm 0.36$ \\
CP medial & $3.96 \pm 0.22$ & $4.06 \pm 0.16$ & $4.03 \pm 0.40$ \\
Amygdala & $2.36 \pm 0.13$ & $2.97 \pm 0.19^{a}$ & $3.85 \pm 0.32^{b}$ \\
CA 1 & $9.19 \pm 0.60$ & $9.22 \pm 0.28$ & $9.65 \pm 0.60$ \\
Adenosine A A receptor mRNA & & \\
Nucleus accumbens & $21.5 \pm 0.42$ & $19.1 \pm 1.70$ & $19.6 \pm 0.60$ \\
Rostral CP lateral & $28.8 \pm 0.67$ & $24.3 \pm 0.49^{c}$ & $25.6 \pm 0.51$ \\
Rostral CP middle & $28.1 \pm 0.45$ & $23.9 \pm 0.65^{c}$ & $26.6 \pm 0.31^{b}$ \\
Rostral CP medial & $24.7 \pm 0.59$ & $20.5 \pm 0.57^{c}$ & $24.1 \pm 0.30^{b}$
\end{tabular}

Values for caudate-putamen (CP) and the hippocampal area CA 1 are taken +1.20 $\mathrm{mm}$ and $-3.14 \mathrm{~mm}$ from bregma, respectively. The actual locations of the measurements and the abbreviations used here are presented in Figure 4. One-way ANOVA followed by Bonferroni's test was used for multiple comparisons.

${ }^{a}$ Difference between water + saline and caffeine + saline; $p<0.05$.

${ }^{b}$ Difference between caffeine + saline and caffeine (withdrawal) + saline; $p<0.01$.

${ }^{c}$ Difference between water + saline and caffeine + saline; $p<0.001$.

\section{Effects of chronic caffeine treatment on NGFI-A mRNA}

To assess a functional correlate to the above-mentioned alterations in the levels of adenosine receptors, we examined alterations in the levels of NGFI-A mRNA. Its expression as well as that of some other immediate early genes such as c-fos is likely to correlate with neuronal activity in striatum, at least after acute treatments (Chergui et al., 1997; Gonon, 1997). However, we can only assume that there is also a correlation between neuronal activity and NGFI-A mRNA in animals treated chronically with caffeine. There was a relatively high expression of NGFI-A mRNA in striatum in water+saline-treated animals (Table 4, Fig. $8 A, E)$. Nevertheless, a significant increase in the expression of this gene was detected in the rostromedial aspect of striatum and in nucleus accumbens of animals exposed to caffeine for $14 \mathrm{~d}$ (Table 4, Fig. 8A,C). Moreover, caffeine + saline-treated animals also had significantly higher levels of NGFI-A mRNA in the cingulate cortex than water+saline-treated animals. In caffeine(withdrawal) + saline-treated animals, the upregulation of NGFI-A mRNA in the striatum and the cingulate cortex had returned to control levels and tended to be normalized also in the nucleus accumbens (Table 4).

\section{Effects of a challenge with caffeine on NGFI-A mRNA in nontolerant and tolerant animals}

There was a decrease in the expression of NGFI-A mRNA throughout rostral parts of striatum and in nucleus accumbens in water + caffeine-treated animals, but an increase in the rostral part of the hippocampal area CA1 when compared with water+saline-treated animals (Table 4, Fig. 8A,B,E,F,IJJ,M,N). The levels of NGFI-A mRNA in the somatosensory and motor parts of cerebral cortex, the lateral amygdala, and the caudal part of the hippocampal area CA 1 tended also to be higher in animals treated with water+caffeine than in those treated with water+saline (Table 4, Fig. 8I,J).

Similarly, in chronically caffeine-treated animals a challenge with caffeine had a tendency, albeit not significant, to reduce the expression of NGFI-A mRNA throughout rostral parts of striatum (Table 4, Fig. $8 C, D, G, H$ ). Furthermore, there was a trend toward an induction of NGFI-A mRNA in the rostral and caudal parts of the hippocampal area CA 1 and in the lateral amygdala (Table 4, Fig. 8K,L,O,P). When nontolerant (water+caffeine) and tolerant (caffeine + caffeine) animals challenged with caffeine 

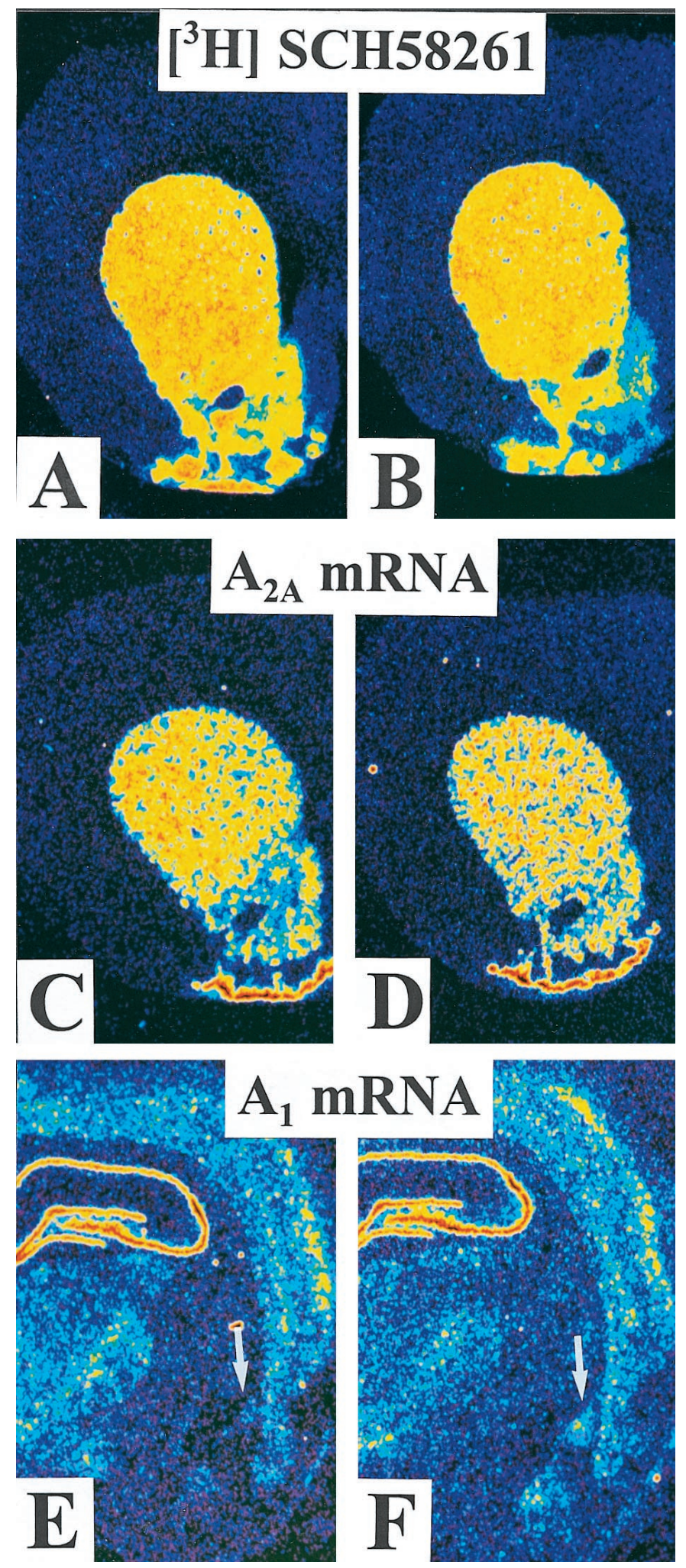

Figure 5. Color-coded photomicrographs showing binding of $\left[{ }^{3} \mathrm{H}\right]$ SCH58261 $(A, B)$ and $\mathrm{A}_{2 \mathrm{~A}}$ receptor mRNA $(C, D),+1.20 \mathrm{~mm}$ from bregma, in water+saline-treated $(A, C)$ and caffeine+saline-treated $(B$, $D)$ animals. $E$ and $F$ show $\mathrm{A}_{1}$ receptor mRNA, $-3.14 \mathrm{~mm}$ from bregma, in water + saline-treated $(E)$ and caffeine + saline-treated $(F)$ animals. The white arrows point to the lateral amygdala. were compared, significantly lower values of NGFI-A mRNA expression in rostral parts of striatum were found in the nontolerant animals (Table 4, Fig. 8B,D).

\section{There are no effects of oral caffeine treatment on tyrosine hydroxylase mRNA levels in the substantia nigra pars compacta and the ventral tegmental area}

There is abundant evidence that an intact dopaminergic neurotransmission is necessary for caffeine to be stimulatory (Ferré et al., 1992). Chronic treatment with morphine and cocaine that leads to reverse tolerance (i.e., sensitization) is accompanied by increased levels of tyrosine hydroxylase in the mesencephalon (Beitner-Johnson and Nestler, 1991). To examine whether induced changes in this enzyme (which catalyzes the rate-limiting step in catecholamine synthesis) could explain the development of tolerance to caffeine, we examined expression of tyrosine hydroxylase mRNA in substantia nigra pars compacta and the ventral tegmental area in animals chronically exposed to caffeine. However, no significant differences were found between animals treated with water + saline (optical density values $1.047 \pm 0.016$ and $1.052 \pm 0.019$ for substantia nigra and the ventral tegmental area, respectively), caffeine + saline (optical density values $1.058 \pm$ 0.011 and $1.053 \pm 0.024$ for substantia nigra and the ventral tegmental area, respectively) or caffeine(withdrawal) + saline (optical density values $1.036 \pm 0.009$ and $1.046 \pm 0.015$ for substantia nigra and the ventral tegmental area, respectively).

\section{DISCUSSION}

Intake of a cup of coffee yields plasma levels of caffeine between 5 and $10 \mu \mathrm{M}$ in humans (Daly, 1993; Fredholm, 1995). This is similar to the plasma levels of caffeine measured in the present study, and the results obtained may be highly relevant for understanding adaptive changes that may occur after coffee consumption in humans.

As in the case of the development of tolerance to psychostimulatory responses of caffeine in humans (Daly, 1993), only an incomplete tolerance to the locomotor stimulatory action of caffeine was observed here. We have purposely avoided using higher doses of caffeine despite the fact that previous work (Holtzman and Finn, 1988; Lau and Falk, 1995) has suggested that the development of tolerance becomes more complete at higher doses of caffeine. We did this because effects of caffeine are biphasic: low doses of caffeine are stimulatory, whereas high doses are inhibitory. We have found previously that stimulatory doses of caffeine decrease striatal expression of immediate early genes, including NGFI-A, but that higher and depressant concentrations increase their expression (Svenningsson et al., 1995a). Thus, there is evidence that the biphasic action of caffeine on locomotion is the result of two independent mechanisms, and it is possible that chronic caffeine administration will differentially affect these mechanisms. The stimulatory effect could be masked by the inhibitory effects, if tolerance develops only to the former or if the inhibitory response becomes sensitized. Either type of adaptation could explain why tolerance to the stimulatory effect of caffeine is insurmountable under some experimental conditions (Holtzman and Finn, 1988; Holtzman et al., 1991). Because changes in NGFI-A mRNA expression after a challenge with caffeine occur in the same areas in nontolerant and tolerant animals, although to a different extent, the present data argue that tolerance to the stimulatory mechanism, rather than sensitization of the inhibitory mechanism, underlies the decreased stimulatory capacity of caffeine in long-term-treated animals. It appears that there are 


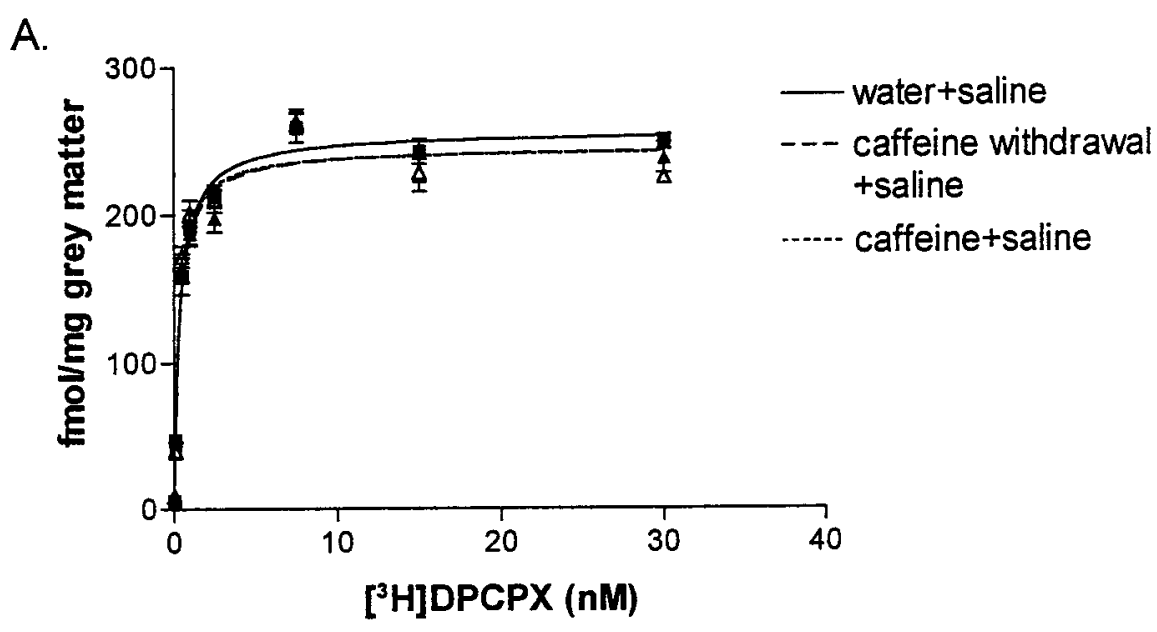

B.

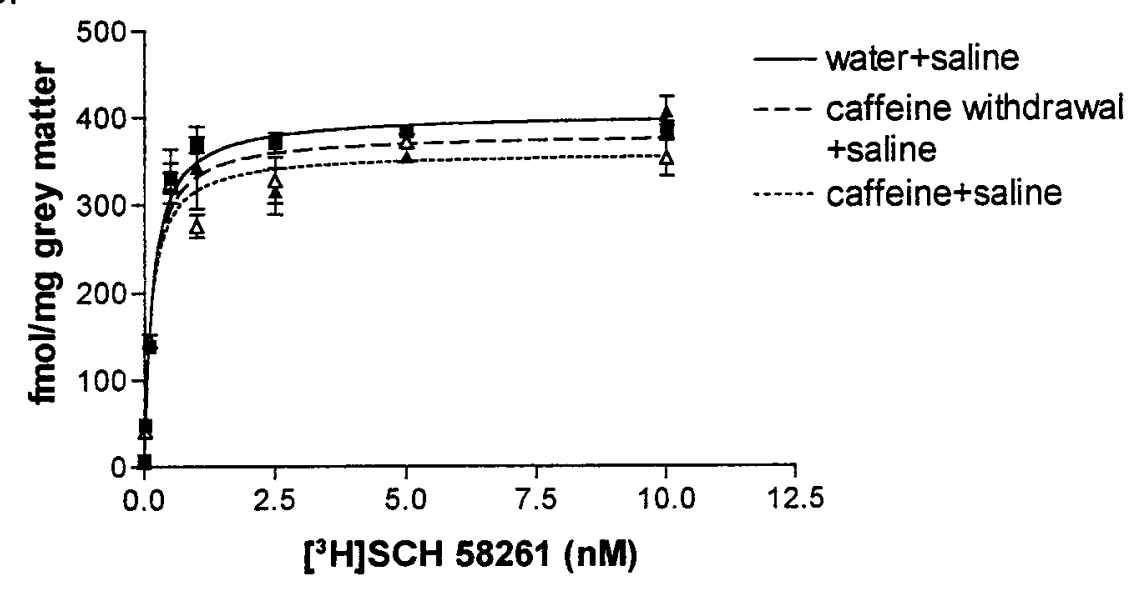

Figure 6. Saturation curves of $\left[{ }^{3} \mathrm{H}\right] \mathrm{DPCPX}$ binding in the CA 1 part of hippocampus $(A)$ and of $\left[{ }^{3} \mathrm{H}\right] \mathrm{SCH} 58261$ binding in the lateral part of rostral striatum $(B)$ from animals treated with water+saline, caffeine + saline, or caffeine(withdrawal)+saline. No significant differences in the $B_{\max }$ and $K_{\mathrm{D}}$ values for $\left[{ }^{3} \mathrm{H}\right] \mathrm{DPCPX}$-binding between the treatment groups were seen in substantia nigra pars reticulata, lateral geniculatum, or the hippocampal areas CA 1, CA 3, and gyrus dentatus. In contrast, $B_{\max }$ values were significantly lower in the rostrolateral $(358 \pm 10.3 \mathrm{fmol} /$ gray matter) and rostromedial $(341 \pm 14.19 \mathrm{fmol} /$ gray matter) parts of striatum in caffeine+saline- as compared with water+saline-treated animals $(402 \pm 7.13$ and $382 \pm 6.10 \mathrm{fmol} /$ gray matter, respectively). No significant differences could be observed between water + saline-treated animals and caffeine(withdrawal)+saline-treated animals that showed $B_{\max }$ values of $380 \pm 13.5$ and $355 \pm$ $16.4 \mathrm{fmol} /$ gray matter in the rostrolateral and rostromedial parts of striatum. No significant changes in $K_{\mathrm{D}}$ values of $\left[{ }^{3} \mathrm{H}\right] \mathrm{SCH} 58261$ (average $0.20 \mathrm{nM}$ ) were seen between the different treatment groups in any of the areas investigated. specific adaptive changes in the brain after chronic caffeine administration.

The present study also shows that the peripheral metabolism of caffeine is enhanced in tolerant animals. Because two of caffeine's metabolites, theophylline and paraxanthine, bind with higher affinity than caffeine to adenosine receptors, the bioavailability of methylxanthines blocking adenosine receptors in the plasma is increased in chronically caffeine-treated animals. However, because passage through the blood-brain barrier is considerably more efficient for caffeine than its metabolites, the enhanced metabolism of caffeine in the periphery does not lead to increased amounts of active methylxanthines in the brain. Conversely, there is no decrease in the amounts of adenosine antagonists in tolerant animals, and altered metabolism cannot explain the development of behavioral tolerance.

It was originally proposed that $\mathrm{A}_{1}$ receptors played an important role in the stimulatory action of caffeine (Snyder et al., 1981), and changes in neurotransmission via $\mathrm{A}_{1}$ receptors may therefore be important for the development of tolerance to caffeine (see introductory remarks). However, the low doses of caffeine used here caused small or no changes in the number of $A_{1}$ receptors and its corresponding mRNA, and only in the lateral amygdala was there a significant upregulation of $A_{1}$ receptor mRNA. This increase may be related not only to the stimulatory effect of caffeine on locomotion but also to caffeine's ability to affect conditioned learning processes, especially those related to fear and anxiety (Daly, 1993; McKernan and Shinnick-Gallagher, 1997; Rogan et al., 1997).
Recent work has emphasized an important role also for striatal $\mathrm{A}_{2 \mathrm{~A}}$ receptors as a target of action for physiologically relevant concentrations of caffeine (Ferré et al., 1992; Barraco et al., 1993; Svenningsson et al., 1995a, 1997c; Ledent et al., 1997). A somewhat surprising novel finding in the present study was that longterm oral treatment with caffeine led to a reduction of $\mathrm{A}_{2 \mathrm{~A}}$ receptors and their corresponding mRNA in striatum. Furthermore, a downregulation of $\mathrm{A}_{2 \mathrm{~A}}$ receptor mRNA after both acute and repeated intraperitoneal injections with caffeine was found. The transcription factors whereby caffeine regulates expression of the $A_{2 A}$ receptor gene remain to be determined. In the present study, we found no direct involvement of c-fos-containing AP-1.

Pharmacological principles suggest that downregulation of a receptor would lead to a smaller functional response to an agonist but not to a competitive antagonist, such as caffeine. Hence one could argue, as was done by Holtzman and coworkers (1991) in the case of $A_{1}$ receptors, that alterations in receptor number are not relevant to explain the tolerance to an antagonist such as caffeine. Nonetheless, the downregulation of $\mathrm{A}_{2 \mathrm{~A}}$ receptors might be relevant as a partial explanation. Frequently a decrease in the number of receptors leads to a leftward shift of the concentration-response curve for an agonist, and this was also demonstrated recently for $\mathrm{A}_{2 \mathrm{~A}}$ receptors (Arslan et al., 1999). Provided that the concentration of adenosine does not increase in the brain after long-term caffeine treatment, one would expect a smaller activation of $\mathrm{A}_{2 \mathrm{~A}}$ receptors by endogenous adenosine and hence a smaller biological effect of caffeine.

$\mathrm{A}_{2 \mathrm{~A}}$ receptors are highly expressed in striatopallidal neurons 


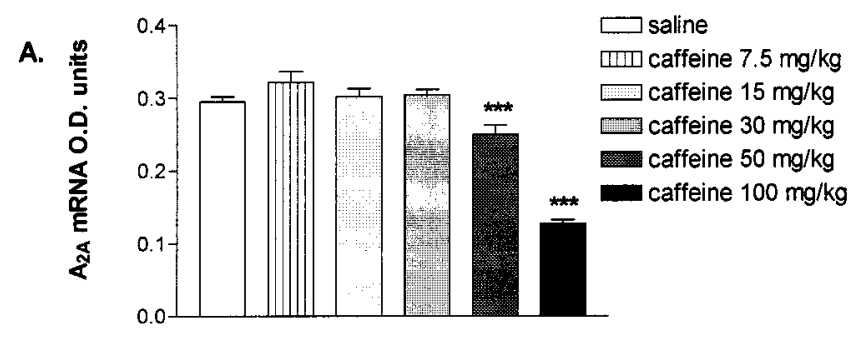

B.
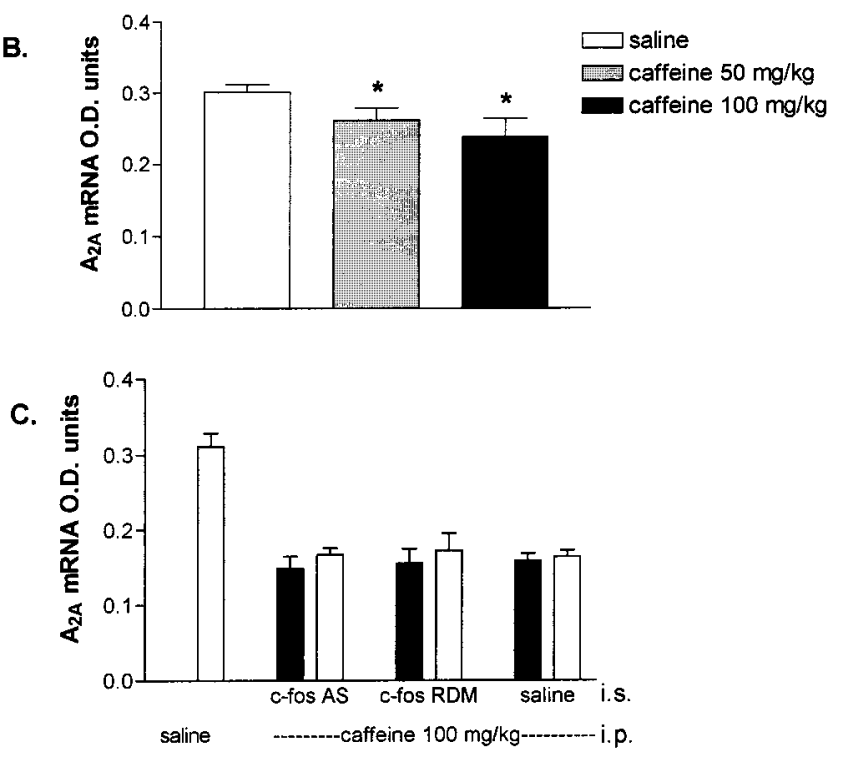

Figure 7. Histograms showing the effects of acute $(A)$ or chronic $(B)$ intraperitoneal administration of caffeine, at the indicated doses, on $\mathrm{A}_{2 \mathrm{~A}}$ receptor mRNA. In $C$, the lack of effect of pretreatment with c-fos antisense oligonucleotide on reductions in $\mathrm{A}_{2 \mathrm{~A}}$ receptor mRNA is shown.

where they are colocalized with dopamine $\mathrm{D}_{2}$ receptors (Schiffmann et al., 1991; Fink et al., 1992; Schiffmann and Vanderhaeghen, 1993; Svenningsson et al., 1997b). This subpopulation of neurons is one of the two neuronal pathways from striatum; the other projects to substantia nigra-nucleus entopeduncularis (Gerfen and Wilson, 1996). Most psychostimulants, including cocaine, amphetamine, and nicotine, increase the expression of immediate early genes such as c-fos and NGFI-A in striatonigral neurons (Gerfen and Wilson, 1996). By contrast, caffeine, at low doses, has no pronounced effects on immediate early gene expression in these neurons but decreases their expression in striatopallidal neurons (Svenningsson et al., 1995a, 1997c). Thus, it seems that blockade of $\mathrm{A}_{2 \mathrm{~A}}$ receptors is crucial for the stimulatory action of caffeine and that caffeine may increase locomotion through an atypical mechanism.

The decreased ability of caffeine to reduce striatal NGFI-A mRNA in tolerant animals as compared with nontolerant animals implies that functionally relevant adaptations in striatopallidal neurons may underlie the development of tolerance to the stimulatory effects of caffeine on locomotion. Such a mechanism receives further support from the observation that an acute injection, but not repeated injections, of stimulatory doses of caffeine induces c-fos mRNA in globus pallidus (Svenningsson and Fredholm, 1997). Caffeine-induced pallidal c-fos mRNA is likely to depend, at least partly, on disinhibition of striatopallidal neurons (Svenningsson and Fredholm, 1997). Thus, behavioral tolerance to caffeine is correlated to a reduced effect of caffeine on striatopallidal neurons.

Caffeine caused also a pronounced increase in NGFI-A mRNA in the CA 1 part of the hippocampal formation and a trend toward an increase in the lateral part of amygdala. Because both of these regions contain a large number of $A_{1}$ receptors, the caffeinemediated effects in these extrastriatal areas may reflect actions on $\mathrm{A}_{1}$ receptor-containing neuronal pathways that could be involved in modulation by adenosine of synaptic plasticity because NGFI-A expression correlates well with the persistence of longterm potentiation in hippocampus (Cole et al., 1989; Daly, 1993). Because hippocampus and the lateral amygdala send excitatory projections to striatum, an altered neuronal activity in these areas may also be involved in the adaptive neurochemical changes in striatal gene expression that were associated with the development of locomotor tolerance in long-term caffeine-treated animals (Gerfen and Wilson, 1996; Swanson and Petrovich, 1998).

In conclusion, the present findings suggest that changes in immediate early gene expression, probably reflecting altered neuronal activity, in some specific areas correlate with the stimula-

Table 4. Optical density values $(\times 100)$ of NGFI-A mRNA from some of the examined regions after indicated treatments

\begin{tabular}{llllll} 
& Water + saline & Water + caffeine & Caffeine + saline & Caffeine + caffeine & Caffeine $+($ withdrawal + saline \\
\hline Nucleus accumbens & $5.78 \pm 0.18^{a}$ & $4.66 \pm 0.24^{b}$ & $6.74 \pm 0.18^{c}$ & $6.20 \pm 0.27$ & $6.43 \pm 0.68$ \\
CP lateral & $6.66 \pm 0.26$ & $5.06 \pm 0.29$ & $8.05 \pm 0.52$ & $6.09 \pm 0.29$ & $7.32 \pm 1.30$ \\
CP middle & $6.89 \pm 0.28^{a}$ & $5.33 \pm 0.24$ & $7.96 \pm 0.42$ & $6.79 \pm 0.33$ & $7.35 \pm 1.06$ \\
CP medial & $6.55 \pm 0.25^{d}$ & $4.64 \pm 0.24^{b}$ & $7.71 \pm 0.49^{c}$ & $6.55 \pm 0.28$ & $6.68 \pm 0.44$ \\
SSC inner & $9.11 \pm 0.75$ & $11.4 \pm 3.63$ & $9.41 \pm 1.23$ & $7.49 \pm 0.55$ & $8.27 \pm 1.16$ \\
MC inner & $8.53 \pm 0.28$ & $9.95 \pm 0.71$ & $9.16 \pm 0.55$ & $8.36 \pm 0.39$ & $8.82 \pm 1.67$ \\
CC & $11.2 \pm 0.48$ & $12.1 \pm 0.58$ & $14.8 \pm 0.50^{e}$ & $12.4 \pm 0.90$ & $10.7 \pm 1.85^{f}$ \\
Amygdala & $10.6 \pm 2.09$ & $13.3 \pm 4.03$ & $9.19 \pm 1.27$ & $10.8 \pm 1.83$ & $9.75 \pm 1.07$ \\
CA 1 & $18.5 \pm 0.88^{a}$ & $22.1 \pm 0.58$ & $18.4 \pm 0.44$ & $21.1 \pm 1.24$ & $17.7 \pm 1.00$
\end{tabular}

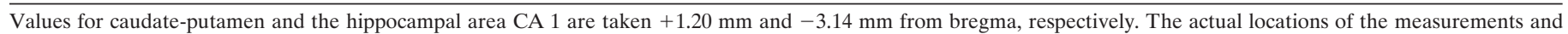
the abbreviations used here are presented in Figure 4. One-way ANOVA followed by Bonferroni's test was used for multiple comparisons.

${ }^{a}$ Difference between water+saline and water+caffeine; $p<0.05$.

${ }^{b}$ Difference between water + caffeine and caffeine + caffeine; $p<0.01$.

${ }^{c}$ Difference between water + saline and caffeine + saline; $p<0.05$.

${ }^{d}$ Difference between water + saline and water + caffeine; $p<0.001$.

${ }^{e}$ Difference between water + saline and caffeine + saline; $p<0.01$.

${ }^{f}$ Difference between caffeine + saline and caffeine(withdrawal) + saline; $p<0.05$. 

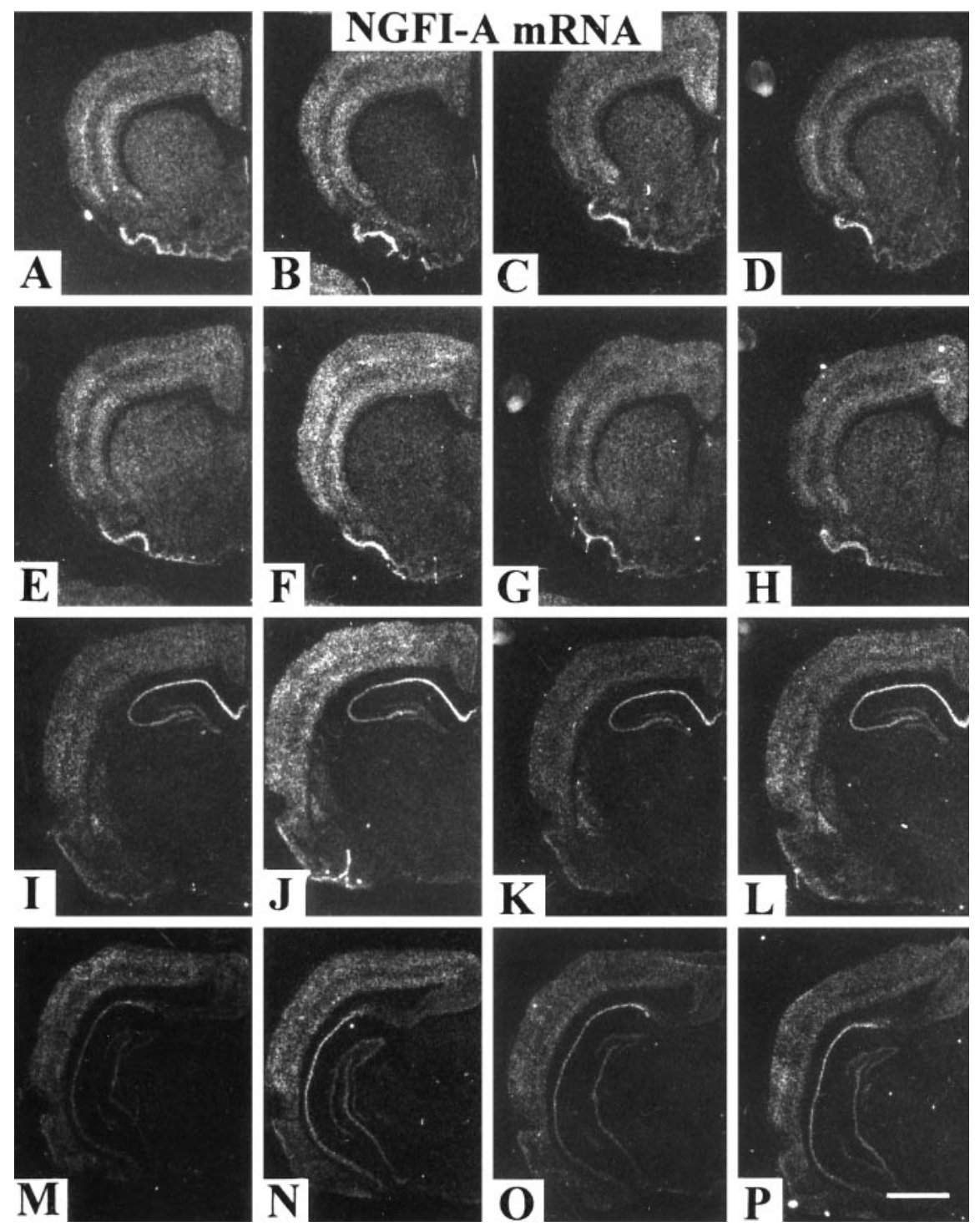

Figure 8. Dark-field photomicrographs showing NGFI-A mRNA expression at $+1.20 \mathrm{~mm}(A-D)$, $+0.48 \mathrm{~mm}(E-H),-3.14 \mathrm{~mm}(I-L)$, and $-5.20 \mathrm{~mm}$ $(M-P)$ from bregma after water+saline $(A, E, I, M)$, water+caffeine $(B, F, J, N)$, caffeine + saline $(C, G$, $K, O)$, and caffeine + caffeine $(D, H, L, P)$. tory action of caffeine in nontolerant as well as tolerant animals. Alterations in gene expression in striatum are suggested to be crucial for the development of tolerance to caffeine. This conclusion is further supported by the fact that all extrastriatal regions that respond with an altered gene expression to caffeine send excitatory projections to striatum.

\section{REFERENCES}

Arslan G, Kull B, Fredholm BB (1999) Signaling via $A_{2 A}$ adenosine receptors in four PC 12 cell clones. Naunyn Schmiedebergs Arch Pharmacol 359:28-32.

Barraco RA, Martens KA, Parizon M, Normile HJ (1993) Adenosine $\mathrm{A}_{2 \mathrm{a}}$ receptors in the nucleus accumbens mediate locomotor depression. Brain Res Bull 31:397-404.

Beitner-Johnson D, Nestler EJ (1991) Morphine and cocaine exert common chronic actions on tyrosine hydroxylase in dopaminergic brain reward regions. J Neurochem 57:344-347.

Boissier JR, Simon P (1965) Action de la cafeine sur la motilite spontanee de la souris. Arch Int Pharmacodyn Ther 158:212-221.

Brockwell NT, Eikelboom R, Beninger RJ (1991) Caffeine-induced place and taste conditioning: production of dose-dependent preference and aversion. Pharmacol Biochem Behav 38:513-517.

Carlezon Jr WA, Thome J, Olson VG, Lane-Ladd SB, Brodkin ES, Hiroi N, Duman RS, Neve RL, Nestler EJ (1998) Regulation of cocaine reward by CREB. Science 282:2272-2275.
Chergui K, Svenningsson P, Nomikos GG, Gonon F, Fredholm BB, Svensson TH (1997) Increased expression of NGFI-A mRNA in the rat striatum following burst stimulation of the medial forebrain bundle. Eur J Neurosci 9:2370-2382.

Chu YY, Tu KH, Lee YC, Kuo ZJ, Lai HL, Chern Y (1996) Characterization of the rat $\mathrm{A}_{2 \mathrm{a}}$ adenosine receptor gene. DNA Cell Biol 15:329-337.

Cole AJ, Saffen DW, Baraban JM, Worley PF (1989) Rapid increase of an immediate early gene messenger RNA in hippocampal neurons by synaptic NMDA receptor activation. Nature 340:474-476.

Daly JW (1993) Mechanism of action of caffeine. In: Caffeine, coffee, and health (Garattini S, ed), pp 97-150. New York: Raven.

Dragunow M, Faull RLM (1989) The use of c-fos as a metabolic marker in neuronal pathway tracing. J Neurosci Methods 29:261-265.

Ericson E, Samuelsson J, Ahlenius S (1991) Photocell measurements of rat motor activity. A contribution to sensitivity and variation in behavioral observations. J Pharmacol Methods 25:111-122.

Ferré S, Fuxe K, von Euler G, Johansson B, Fredholm BB (1992) Adenosine-dopamine interactions in the brain. Neuroscience 51:501-512.

Fink JS, Weaver DR, Rivkees SA, Peterfreund RA, Pollack AE, Adler EM, Reppert SM (1992) Molecular cloning of the rat $A_{2}$ adenosine receptor: selective co-expression with $\mathrm{D}_{2}$ dopamine receptors in rat striatum. Brain Res Mol Brain Res 14:186-195.

Fredholm BB (1980) Are methylxanthine effects due to antagonism of endogenous adenosine? Trends Pharmacol Sci 1:129-132. 
Fredholm BB (1982) Adenosine actions and adenosine receptors after 1 week treatment with caffeine. Acta Physiol Scand 115:283-286.

Fredholm BB (1995) Astra Award Lecture. Adenosine, adenosine receptors and the actions of caffeine. Pharmacol Toxicol 76:93-101.

Fredholm BB, Herrera-Marschitz M, Jonzon B, Lindström K, Ungerstedt U (1983) On the mechanism by which methylxanthines enhance apomorphine-induced rotation behaviour in the rat. Pharmacol Biochem Behav 19:535-541.

Georgiev V, Johansson B, Fredholm BB (1993) Long-term caffeine treatment leads to a decreased susceptibility to NMDA-induced clonic seizures in mice without changes in adenosine $\mathrm{A}_{1}$ receptor number. Brain Res 612:271-277.

Gerfen CR, Wilson CJ (1996) The basal ganglia. In: Handbook of chemical neuroanatomy: integrated systems of the CNS (Swanson LW, Björklund A, Hökfelt T, eds), pp 371-467. Amsterdam: Elsevier Science.

Gonon F (1997) Prolonged and extrasynaptic excitatory action of dopamine mediated by $\mathrm{D} 1$ receptors in the rat striatum in vivo. J Neurosci 17:5972-5978.

Holtzman SG, Finn IB (1988) Tolerance to behavioral effects of caffeine in rats. Pharmacol Biochem Behav 29:411-418.

Holtzman SG, Mante S, Minneman KP (1991) Role of adenosine receptors in caffeine tolerance. J Pharmacol Exp Ther 256:62-68.

Jacobson KA, Nikodijevic O, Padgett WL, Gallo-Rodriguez C, Maillard M, Daly JW (1993) 8-(3-Chlorostyryl) caffeine (CSC) is a selective $\mathrm{A}_{2}$-adenosine antagonist in vitro and in vivo. FEBS Lett 323:141-144.

Johansson B, Ahlberg S, van der Ploeg I, Brené S, Lindefors N, Persson $H$, Fredholm BB (1993) Effect of long term caffeine treatment on $A_{1}$ and $\mathrm{A}_{2}$ adenosine receptor binding and on mRNA levels in rat brain. Naunyn Schmiedebergs Arch Pharmacol 347:407-414.

Johansson B, Georgiev V, Lindström K, Fredholm BB (1997) $A_{1}$ and $A_{2 A}$ adenosine receptors and $A_{1}$ mRNA in mouse brain: effect of long-term caffeine treatment. Brain Res 762:153-164.

Kaplan GB, Greenblatt DJ, Kent MA, Cotreau-Bibbo MM (1993) Caffeine treatment and withdrawal in mice: relationships between dosage, concentrations, locomotor activity and $\mathrm{A}_{1}$ adenosine receptor binding. J Pharmacol Exp Ther 266:1563-1572.

Lamouroux A, Faucon Biguet N, Samolyk D, Privat A, Salomon JC, Pujol JF, Mallet J (1982) Identification of cDNA clones coding for rat tyrosine hydroxylase antigen. Proc Natl Acad Sci USA 79:3881-3885.

Lau CE, Falk JL (1995) Dose-dependent surmountability of locomotor activity in caffeine tolerance. Pharmacol Biochem Behav 52:139-143.

Ledent C, Vaugeois JM, Schiffmann SN, Pedrazzini T, Elyacoubi M, Vanderhaeghen JJ, Costentin J, Heath JK, Vassart G, Parmentier M (1997) Aggressiveness, hypoalgesia and high blood pressure in mice lacking the adenosine $\mathrm{A}_{2 \mathrm{~A}}$ receptor. Nature 388:674-678.

Mahan LC, McVittie LD, Smyk-Randall EM, Nakata H, Monsma Jr FJ, Gerfen CR, Sibley DR (1991) Cloning and expression of an $A_{1}$ adenosine receptor from rat brain. Mol Pharmacol 40:1-7.

McKernan MG, Shinnick-Gallagher P (1997) Fear conditioning induces a lasting potentiation of synaptic currents in vitro. Nature 390:607-611.

Milbrandt J (1987) A nerve growth factor-induced gene encodes a possible transcriptional regulatory factor. Science 238:797-799.

Parkinson FE, Fredholm BB (1990) Autoradiographic evidence for G-protein coupled $\mathrm{A}_{2}$-receptors in rat neostriatum using $\left[{ }^{3} \mathrm{H}\right]$-CGS 21680 as a ligand. Naunyn Schmiedebergs Arch Pharmacol 342:85-89.

Ramkumar V, Bumgarner JR, Jacobson KA, Stiles GL (1988) Multiple components of the $\mathrm{A}_{1}$ adenosine receptor-adenylate cyclase system are regulated in rat cerebral cortex by chronic caffeine ingestion. J Clin Invest 82:242-247.

Rogan MT, Staubli UV, LeDoux JE (1997) Fear conditioning induces associative long-term potentiation in the amygdala. Nature 390:604-607.

Saitoh O, Saitoh Y, Nakata H (1994) Regulation of $\mathrm{A}_{2 \mathrm{a}}$ adenosine receptor mRNA expression by agonists and forskolin in PC12 cells. NeuroReport 5:1317-1320.

Schiffmann SN, Libert F, Vassart G, Dumont JE, Vanderhaeghen JJ (1990) A cloned G protein-coupled protein with a distribution restricted to striatal medium-sized neurons. Possible relationship with D1 dopamine receptor. Brain Res 519:333-337.

Schiffmann SN, Jacobs O, Vanderhaeghen JJ (1991) Striatal restricted adenosine $\mathrm{A}_{2}$ receptor (RDC8) is expressed by enkephalin but not by substance $\mathrm{P}$ neurons: an in situ hybridization histochemistry study. J Neurochem 57:1062-1067.

Schiffmann SN, Vanderhaeghen JJ (1993) Adenosine $A_{2}$ receptors regulate the gene expression of striatopallidal and striatonigral neurons. J Neurosci 13:1080-1087.

Sheng M, Greenberg ME (1990) The regulation and function of c-fos and other immediate early genes in the nervous system. Neuron 4:477-485.

Snyder SH, Katims JJ, Annau Z, Bruns RF, Daly JW (1981) Adenosine receptors and behavioral actions of methylxanthines. Proc Natl Acad Sci USA 78:3260-3264.

Svenningsson P, Fredholm BB (1997) Caffeine mimics the effect of a dopamine $\mathrm{D}_{2 / 3}$ receptor agonist on the expression of immediate early genes in globus pallidus. Neuropharmacology 36:1309-1317.

Svenningsson P, Nomikos GG, Fredholm BB (1995a) Biphasic changes in locomotor behavior and in expression of mRNA for NGFI-A and NGFI-B in rat striatum following acute caffeine administration. J Neurosci 15:7612-7624.

Svenningsson P, Ström A, Johansson B, Fredholm BB (1995b) Increased expression of c-jun, junB, AP-1, and preproenkephalin mRNA in rat striatum following a single injection of caffeine. $J$ Neurosci 15:3583-3593.

Svenningsson P, Georgieva J, Kontny E, Heilig M, Fredholm BB (1997a) Caffeine regulates the preprotachykinin $\mathrm{A}$ and neurotensin/neuromedin $\mathrm{N}$ genes via a c-fos dependent mechanism in rat striatum. Eur J Neurosci 9:2135-2141.

Svenningsson P, Le Moine C, Kull B, Sunahara R, Bloch B, Fredholm BB (1997b) Cellular expression of adenosine $A_{2 A}$ receptor messenger RNA in the rat central nervous system with special reference to dopamine innervated areas. Neuroscience 80:1171-1185.

Svenningsson P, Nomikos GG, Ongini E, Fredholm BB (1997c) Antagonism of adenosine $\mathrm{A}_{2 \mathrm{~A}}$ receptors underlies the behavioural activating effect of caffeine and is associated with reduced expression of messenger RNA for NGFI-A and NGFI-B in caudate-putamen and nucleus accumbens. Neuroscience 79:753-764.

Swanson LW, Petrovich GD (1998) What is the amygdala? Trends Neurosci 21:323-331.

Thithapandha A, Maling HM, Gillette JR (1972) Effects of caffeine and theophylline on activity of rats in relation to brain xanthine concentrations. Proc Soc Exp Biol Med 139:582-586.

Tsai-Morris CH, Cao X, Sukhatme VP (1988) 5' flanking sequence and genomic structure of EGR-1, a murine mitogen inducible zinc finger encoding gene. Nucleic Acids Res 16:8835-8846. 